\title{
Unexpected diversity and a new species of Epizoanthus (Anthozoa, Hexacorallia) attached to eunicid worm tubes from the Pacific Ocean
}

\author{
Hiroki Kise', James Davis Reimer ${ }^{1,2}$ \\ I Molecular Invertebrate Systematics and Ecology Laboratory, Graduate School of Engineering and Science, \\ University of the Ryukyus, 1 Senbaru, Nishihara, Okinawa 903-0213, Japan 2 Tropical Biosphere Research \\ Center, University of the Ryukyus, 1 Senbaru, Nishihara, Okinawa 903-0213, Japan
}

Corresponding author: Hiroki Kise (hkm11sea@yahoo.co.jp)

Academic editor: B. W. Hoeksema | Received 18 August 2015 | Accepted 25 November 2015 | Published 10 February 2016

http://zoobank.org/9A5B29AC-14D1-4879-8C55-DD8515557548

Citation: Kise H, Reimer JD (2016) Unexpected diversity and a new species of Epizoanthus (Anthozoa, Hexacorallia) attached to eunicid worm tubes from the Pacific Ocean. Title. ZooKeys 562: 49-71. doi: 10.3897/zookeys.562.6181

\begin{abstract}
Epizoanthus species are generally found in association with other marine invertebrates such as hermit crabs and gastropods. Although Epizoanthus spp. are relatively common, there is limited information about their diversity and ecology due to their habitats or hosts, often being below the depths of SCUBA diving $(>-50 \mathrm{~m})$. In particular, the Epizoanthus fauna of the Indo-Pacific Ocean remains poorly understood. In this study, the diversity of Epizoanthus species associated with eunicid worm tubes from shallow waters in the Pacific Ocean we investigated using molecular analyses (mitochondrial cytochrome oxidase subunit 1 $=\mathrm{COI}$, mitochondrial $16 \mathrm{~S}$ ribosomal DNA = mt 16S-rDNA, nuclear internal transcribed spacer region of ribosomal DNA = ITS-rDNA) combined with morphological and ecological data. The combined data set leads us to describe two new species; Epizoanthus inazuma sp. n. and Epizoanthus beriber sp. n. Both new species are found in low-light environments: E. inazuma sp. n. on mesophotic coral reef slopes and reef floors, or on the sides of overhangs; E. beriber sp. n. has only been found in caves. Morphological characteristics of these two new species are very similar to E. illoricatus Tischbierek, 1930 but the two new species are genetically distinct. Mesentery numbers and coloration of polyps may be useful diagnostic characteristics among eunicid-associated Epizoanthus species. These results demonstrate that there is high potential for other potentially undescribed zoantharian species, particularly in underwater cave habitats.
\end{abstract}

Copyright H. Kise \& J. D. Reimer. This is an open access article distributed under the terms of the Creative Commons Attribution License (CC BY 4.0), which permits unrestricted use, distribution, and reproduction in any medium, provided the original author and source are credited. 


\section{Keywords}

Eunicidae, cryptic species, mesophotic, molecular analyses, underwater cave, zoantharian

\section{Introduction}

The order Zoantharia is currently separated into two suborders (Haddon and Shackleton 1891): Macrocnemina and Brachycnemina. The suborders are distinguished by differences in the fifth pair of mesenteries from the dorsal directive, which are complete in the suborder Macrocnemina and incomplete in the suborder Brachycnemina. The suborder Macrocnemina is currently composed of five families: Epizoanthidae, Hydrozoanthidae, Microzoanthidae, Nanozoanthidae, and Parazoanthidae. Most species of Macrocnemina to the exception of Microzoanthidae and Nanozoanthidae are often found in association with other marine invertebrates. The family Epizoanthidae can be distinguished from other macrocnemic zoantharians by the presence of a simple mesogloeal sphincter muscle.

The family Epizoanthidae consists of three genera: Epizoanthus, Palaeozoanthus, and Thoracactis. The genus Palaeozoanthus has not been found or examined in detail since its original description (Carlgren 1924), while Thoracactis topsenti Gravier, 1918 is the sole representative of its genus and is an epibiont on sponges at 800-1100 meters around the Cape Verde Islands (Gravier 1918). The type genus of Epizoanthidae, Epizoanthus, includes species that have epibiotic associations with hermit crabs (Muirhed et al. 1986; Ates 2003; Reimer et al. 2010a; Schejter and Mantelatto 2011), molluscs (Rees 1967), eunicid worms (Sinniger et al. 2005), or the stalks of glass sponges (hexactinellids) (Beaulieu 2001). Epizoanthus spp. have been reported worldwide, including from the northeast Atlantic (Muirhead et al. 1986), the Caribbean Sea (Duerden 1898), and both the eastern (Carlgren 1899; Philipp and Fautin 2009; Sinniger et al. 2009) and western Pacific (Haddon and Shackleton 1891; Reimer et al. 2010a).

Although Epizoanthus spp. are relatively common, little research has been conducted on the ecology and taxonomy of this genus (Ates 2003). Many Epizoanthus species are known from below the depth limits safe for SCUBA diving $(>-50 \mathrm{~m})$, making collection and observation difficult. Epizoanthus species are also often difficult to identify due to lack of external diagnostic characteristics, and data are often limited to polyp size, oral disk color, and tentacle count (Reimer et al. 2010a). It is often difficult to observe zoantharian internal morphology due to sand encrustation in their epithelial/endodermal tissue, making thin cross sections difficult without compromising histology (Reimer et al. 2010b). Molecular phylogenetic analyses have been used to overcome these issues and to help understand zoantharian diversity and taxonomy (e.g. Burnett 1997; Reimer et al. 2006; Sinniger et al. 2008; Fujii and Reimer 2011). For example, Epizoanthus species diversity in Japan has been preliminarily investigated by using molecular methods and potentially undescribed species were found (Sinniger et al. 2009; Reimer et al. 2010a). Thus, molecular methods are an effective tool to help clarify the taxonomy and diversity of Epizoanthus species. 
There are several described Epizoanthus species which are free-living, carcinoeciumforming, or epizoic on gastropods or glass sponges from the Pacific Ocean, such as E. paguriphilus Verrill, 1883 from the East China Sea; E. stellaris Hertwig, 1888 from the Philippines; E. patagonichus Carlgren, 1899 from Chile; E. indicus (Lwowsky, 1913) from the East China Sea; E. illoricatus Tischbierek, 1930 from Manila; E. ramosus Carlgren, 1936 from the East China Sea; E. scotinus Wood, 1957 from the Pacific Northwest; E. sabulosus Cutress, 1971 from Australia; E. giveni Philipp \& Fautin, 2009 from California, and E. fiordicus Sinniger \& Haussermann, 2009 from Chile. For Epizoanthus spp. attached to zig-zag shaped eunicid worm tubes, all have been identified as E. illoricatus since the species' original description. Eunicid worms are distributed in marine benthic environments around the world and are especially common in shallow tropical waters (Fauchald 1992). The family Eunicidae is currently composed of eight valid genera and -330 species (Zanol et al. 2013), some of which are known to have associations with various marine invertebrates such as cnidarians, sponges and mollusks (Martin and Britayev 1998; Neves and Omena 2003). Recently, Reimer et al. (2014) investigated the diversity of zoantharians in the central IndoPacific and suggested that there are may be at least two species within E. illoricatus. However, no taxonomic conclusions were reached in this study.

In the current study the diversity of Epizoanthus species attached to eunicid worm tubes we investigated via molecular phylogenetic analyses utilizing three DNA markers; nuclear internal transcribed spacer of ribosomal DNA (ITS-rDNA), mitochondrial 16S ribosomal DNA (mt 16S-rDNA), and cytochrome oxidase subunit I (COI), and nuclear internal transcribed spacer of ribosomal DNA (ITS-rDNA). We then combined molecular results with morphological data (polyp dimensions, polyp arrangement and density within colonies, external colony and oral disk color, cnidae analyses, mesenterial patterns and numbers). The combined results of this research indicated the presence of two phylogenetically distinct and previously undescribed species of Epizoanthus associated with eunicid worm tubes in the Pacific Ocean, which we formally describe herein.

\section{Materials and methods}

\section{Specimen collection}

Epizoanthus specimens were collected from three localities in Okinawa, Japan, seven localities in Palau, and one location each in New Caledonia and Papua New Guinea (Figure 1). In total 70 specimens were collected, of which 69 specimens were collected by SCUBA at 10 to $40 \mathrm{~m}$ depth, with one additional specimen collected using the Japan Agency for Marine-Earth Science and Technology (JAMSTEC)'s ROV Hyper-Dolphin from $114 \mathrm{~m}$ during a research cruise in southern Japan in 2012. Collected specimens were preserved in 70-99.5\% ethanol for molecular analyses and/or fixed in 5-10\% seawater formalin and then later preserved in $70 \%$ ethanol for morphological analyses. 


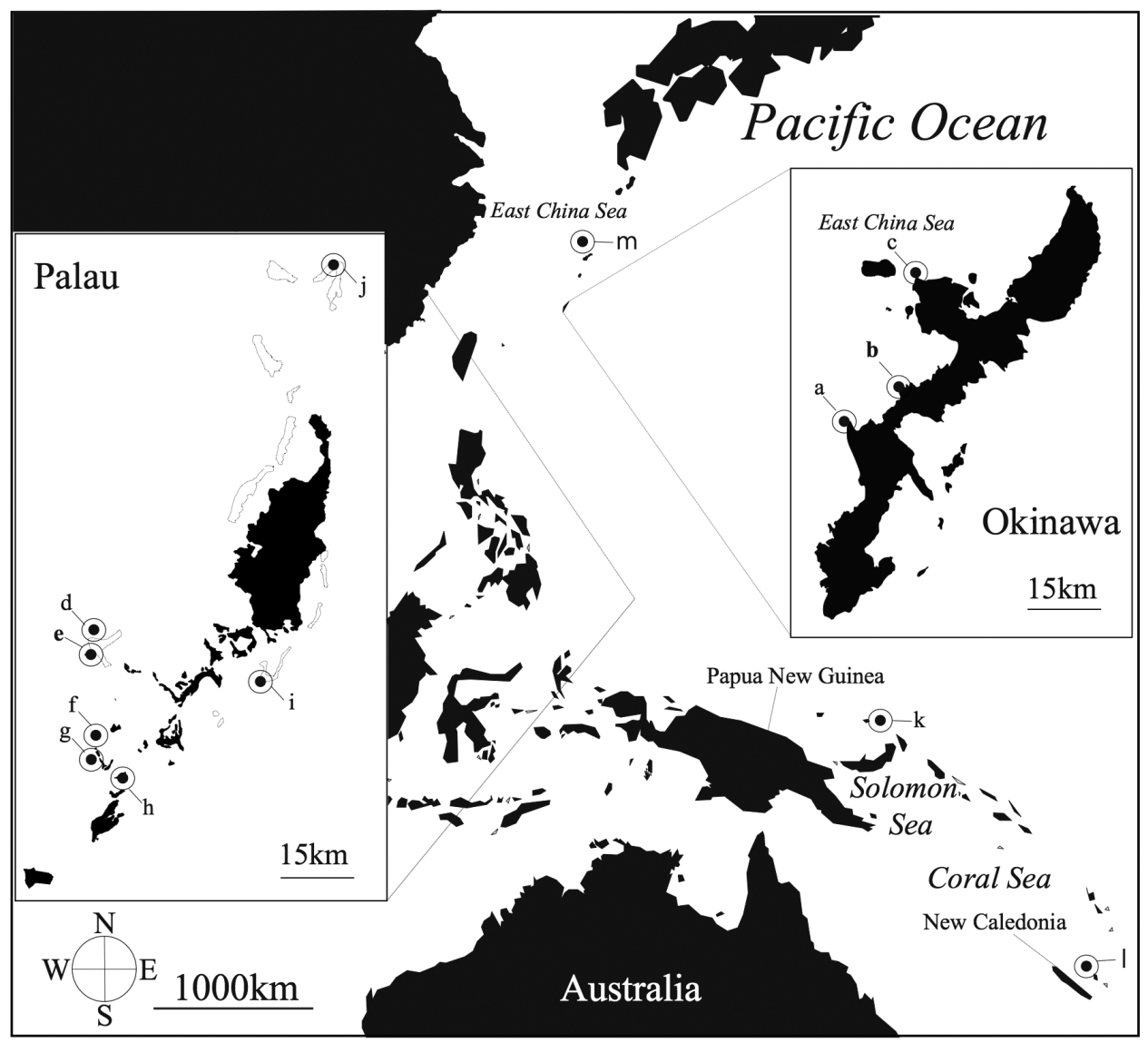

Figure I. Sampling location in the Pacific Ocean of specimens used in this study. Location of specimens collected in this study represented by closed symbols. a Cape Zanpa b Cape Manzamo c Bise d Siaes Corner e Siaes Tunnel $\mathbf{f}$ Blue Hole $\mathbf{g}$ Blue Corner $\mathbf{h}$ Turtle Cove $\mathbf{i}$ Short Drop-off $\mathbf{j}$ Ngeruangel k Mascot Channel I Loyalty Islands $\mathbf{m}$ Kodakara Islands. Location in bold indicate type localities as follows: b $($ Cape Manzamo, Onna, Okinawa, Japan $)=$ E. inazuma sp. n. e $($ Turtle Cove, Palau $)=E$. beriber sp. $\mathrm{n}$.

\section{Morphological analyses}

The lengths and diameters of individual polyps, tentacle lengths and numbers, color of polyps, and diameters of oral disks were measured using in situ images or a dissecting microscope. Additionally, polyp densities of colonies attached to identically sized eunicid worm tubes $(9 \mathrm{~cm}$ in length) were calculated using a counter under a dissecting microscope. For internal morphological analyses, some specimens' polyps were cut into $7 \mu \mathrm{m}$ cross-sections using a microtome after paraffin embedding following Reimer et al. (2010b), and these sections were subsequently stained with hematoxylin and eosin. Specimens to examine were selected from each phylogenetic clade $(n=3 /$ clade $)$ recovered in the molecular analyses. 


\section{Cnidae}

Cnidae classification basically followed England (1991) and Ryland and Lancaster (2004). However, Schmidt (1974), Hidaka et al. (1987), Hidaka (1992), Fujii and Reimer (2011), and Montenegro et al. (2015) have referred to basitrichs and microbasic b-mastigophores as the same type of nematocysts and therefore in this study, these two types were pooled together. We used a Nikon Eclipse80i stereomicroscope (Nikon, Tokyo) to count and examine undischarged cnidae, which were measured using ImageJ software (National Institute of Health, Bethesda, Maryland, Nikon Eclipse80i, Nikon, Tokyo). Specimens to be examined were selected from each phylogenetic clade recovered from the molecular analyses.

\section{DNA extraction, PCR amplification and sequence}

DNA was extracted from tissue preserved in $99.5 \%$ ethanol by following a guanidine extraction protocol (Sinniger et al. 2010) or using a spin-column DNEasy Blood and Tissue Extraction kit (Qiagen, Tokyo). PCR amplification using Hot Star Taq Plus Master Mix Kit (Qiagen, Tokyo) was performed for each of ITS-rDNA (nuclear internal transcribed spacer region of ribosomal DNA), mt 16S-rDNA (mitochondrial 16S ribosomal DNA), and COI (cytochrome oxidase subunit I). The ITS-rDNA region was amplified using the specific primer set ITSf (5'-CTA GTA AGC GCG AGT CAT CAG C-3') and ITSr (5’-GGT AGC CTT GCC TGA TCT GA-3') (Swain 2009). mt 16S-rDNA was amplified using the universal primer 16Sar (5'-CGC CTG TTT ATC AAA AAC AT-3') (Palumbi et al. 1996) and the specific primer $16 \mathrm{SBmoH}$ (5'-CGA ACA GCC AAC CCT TGG3') (Sinniger et al. 2005). The COI gene was amplified using the universal primer set LCO1490 (5'-GGT CAA CAA ATC ATA AAG ATA TTG G-3') and HCO2198 (5'-TAA ACT TCA GGG TGA CCA AAA AAT CA-3') (Folmer et al. 1994). All DNA markers were amplified following the thermal-cycle conditions described in Fujii and Reimer (2011). PCR products were checked using $1.0 \%$ agarose gel electrophoresis. The positive PCR products were cleaned using shrimp alkaline phosphatase (SAP) and Exonuclease I (Takara Bio Inc., Shiga, Japan), and then sequenced by Fasmac (Kanagawa, Japan).

\section{Phylogenetic analyses}

Obtained DNA sequences were initially checked using the Basic Local Alignment Search Tool (BLAST, National Center for Biotechnology Information). Obtained nucleotide sequences for the COI gene, mt 16S-rDNA and ITS-rDNA were aligned by CLUSTAL W ver. 1.83 (Thompson et al. 1994) on default settings supplied by Bioedit ver. 7.0.9.0. (http://www.mbio.ncsu.edu/Bioedit/page2.html). The alignments were inspected by eye and manually edited in Bioedit. Sequences belonging 
to the family Hydrozoanthidae were used as outgroups. In this manner three aligned datasets were generated. All sequence datasets are available upon request from the corresponding author.

For the phylogenetic analyses of ITS-rDNA, mt 16S-rDNA and COI, the same methods were independently applied. The neighbor-joining (NJ) method (Saitou and Nei 1987) was performed using MEGA6 (Tamura et al. 2013), with 1000 replicates of bootstrapping. Maximum-likelihood (ML) analyses were performed using PhyML online (Guindon and Gascuel 2003). PhyML was performed using an input tree generated by BIONJ with the general time-reversible model (Rodriguez et al. 1990) of nucleotide substitution incorporating invariable sites and a discrete gamma distribution (eight categories) $(\mathrm{GTR}+\mathrm{I}+\mathrm{C})$. The proportion of invariable sites, a discrete gamma distribution, and base frequencies of the model were estimated from the dataset. PhyML bootstrap trees (1000 replicates) were constructed using the same parameters as the individual ML trees. Bayesian trees were constructed in Mr Bayes 3.1.2 (Ronquist and Huelsenbesk 2003) under the GTR + I + I- model. One cold and three heated Markov chain Monte Carlo (MCMC) chains with temperature of 0.2 were run for 1,500,000 generations, subsampling frequency of 200 and a burn in length of 700,000 for all alignments.

\section{Results}

\section{Systematics}

Phylum Cnidaria Hatschek, 1888

Class Anthozoa Ehrenberg, 1831

Subclass Hexacorallia Haeckel, 1896

Order Zoantharia Gray, 1832

Suborder Macrocnemina Haddon \& Shackleton, 1891

Family Epizoanthidae Delage \& Hérouard, 1901

Genus Epizoanthus Gray, 1867

\section{Epizoanthus Gray, 1867}

Type species. Epizoanthus papillosus Johnston, 1842.

Synonym. Epizoanthus incrustatus (Dueben \& Koren, 1847) (ICZN 1991: case 2750).

Remark. Herein, we choose to use the ordinal name Zoantharia Gray, 1832 as in the World Register of Marine Species (Hoeksema and Reimer, 2015). Although Zoantharia Gray, 1832, has identical spelling with the supraordinal name Zoantharia de Blainville, 1830, the latter name has fallen from common use-Hexacorallia Haeckel, 1896, being favoured. 


\section{Epizoanthus inazuma sp. $\mathrm{n}$.}

http://zoobank.org/0B91DB0E-A5AC-41CB-B78F-C8E7B8D44C2A

Material examined. Holotype. NSMT-Co1574 (MISE-HK54), 263' $18.3^{\prime \prime N}$, $127^{\circ} 51^{\prime} 02.3^{\prime \prime E}$, Cape Manzamo, Onna Village, Okinawa, Japan, depth $24 \mathrm{~m}$, collected by Hiroki Kise, July 21, 2014, divided in two pieces, one portion fixed in $99.5 \% \mathrm{EtOH}$ and the other in $5-10 \%$ saltwater formalin, deposited in National Museum of Nature and Science, Tokyo, Japan. Paratype 1. RMNH 42100 (MISE-HK9) 26 30'18.3"N, $127^{\circ} 51^{\prime} 02.3^{\prime \prime E}$, Cape Manzamo, Onna Village, Okinawa, Japan, depth $25 \mathrm{~m}$, collected by James D. Reimer, October 21, 2008, fixed in 99.5\% EtOH, deposited in Naturalis Biodiversity Center, Leiden, The Netherlands. Paratype 2. USNM 1296757

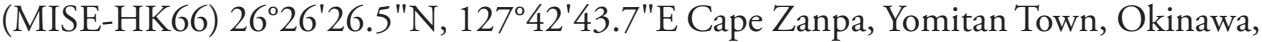
Japan, depth 34 m, collected by Hiroki Kise, August 5, 2014, fixed in 99.5\% EtOH, deposited in Smithsonian Institution National Museum of Natural History, Washington, D.C., USA. Other material. MISE-HK43 2630'18.3"N, 127 51'02.3"E, Cape Manzamo, Onna Village, Okinawa, Japan, depth 30 m, collected by Hiroki Kise, April 5, 2014, fixed in $99.5 \% \mathrm{EtOH}$.

Description of holotype. Colony of approximately 140 polyps connected by thin, under-developed coenenchyme on eunicid worm tubes. The tubes are made of a chitin-like substance. Polyps approximately 0.7 to $1.2 \mathrm{~mm}$ high (=length) from coenenchyme, and 1.0 to $1.65 \mathrm{~mm}$ in diameter. Polyps were attached from base to proximal extremity of zig-zag shaped tubes of eunicid worms, and attached to not only bent sections but also to other locations. Polyp external coloration black, oral disk light brown to brown, lighter nearer the oral opening and darker around oral disk edges. Polyps encrusted with sand and silica particles in their coenenchyme and ectodermal tissue; with few sand particles in the mesoglea.

Diagnosis. Morphology. Polyps connected by thin, under-developed coenenchyme on eunicid worms belonging to family Eunicidae. Maximum diameter of polyps approximately $4 \mathrm{~mm}$, maximum height approximately $5 \mathrm{~mm}$ in situ. Epizoanthus inazuma sp. n. has 20-22 tentacles that are cylindrical and either as long or longer in comparison to oral disk diameter.

Internal anatomy. While the 5th mesentery from dorsal directive is obviously a complete mesentery (macrocnemic arrangement), the 6th mesentery is also a complete mesentery (Figure 2b). Azooxanthellate. Mesogleal thickness approximately $75 \mu \mathrm{m}$.

Cnidae. Holotrichs, basitrichs, microbasic p-mastigophores, spirocysts (see Table 1 into this paper, Figure 3).

Etymology. Epizoanthus inazuma sp. n. is named after the Japanese word 'inazuma' meaning 'lightning', as colonies of this species are attached to eunicid worm tubes, and the worm tube shape resembles a classic lightning-bolt shape. Common Japanese name. 'Inazuma-yadori-sunaginchaku' (new Japanese name).

Distribution and habitat. Epizoanthus inazuma sp. n. is found in low-light environments such as on mesophotic coral reef slopes and reef floors, or on the sides of overhangs. Specimens were collected from 10 to $40 \mathrm{~m}$ depth. 


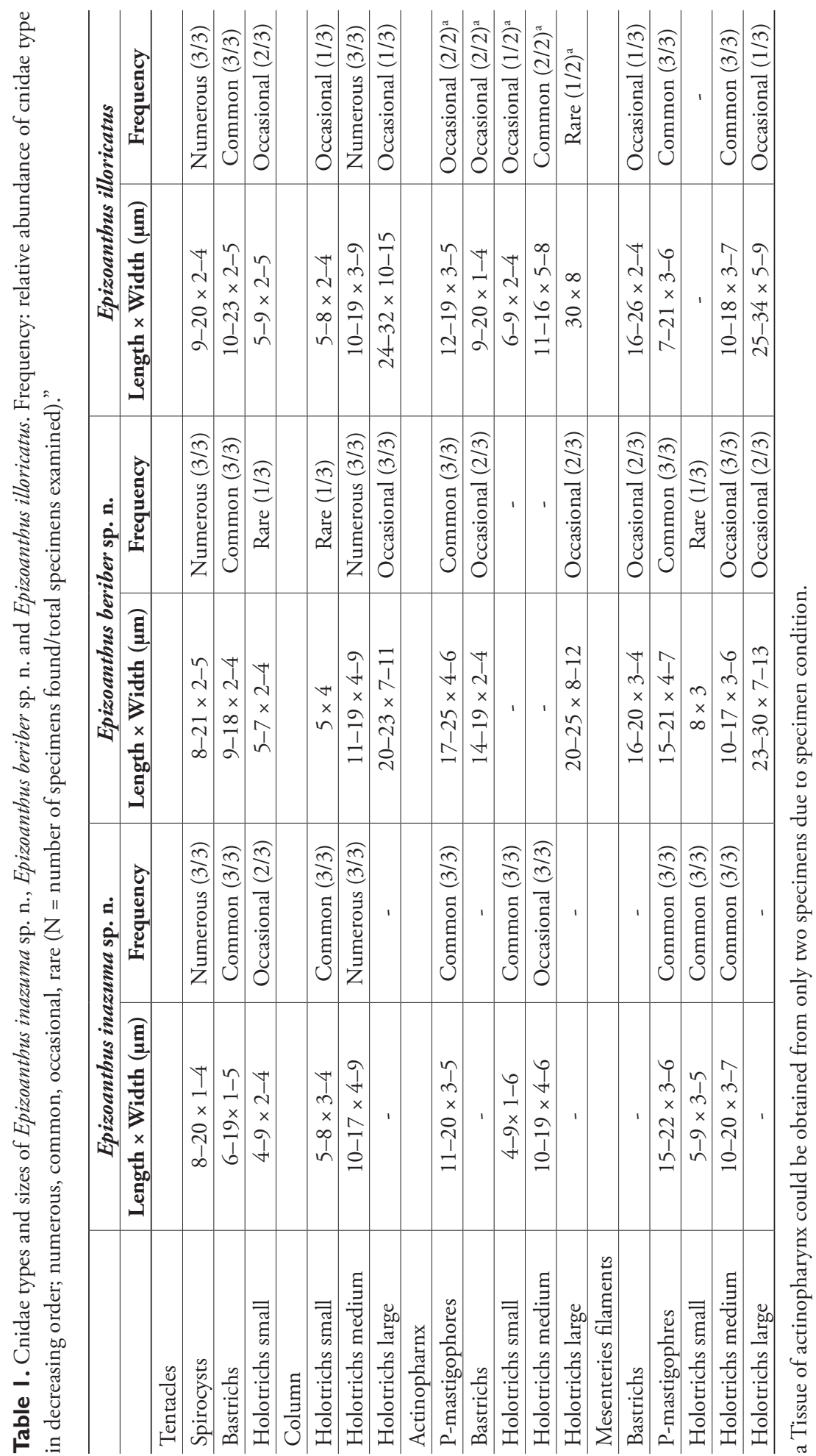



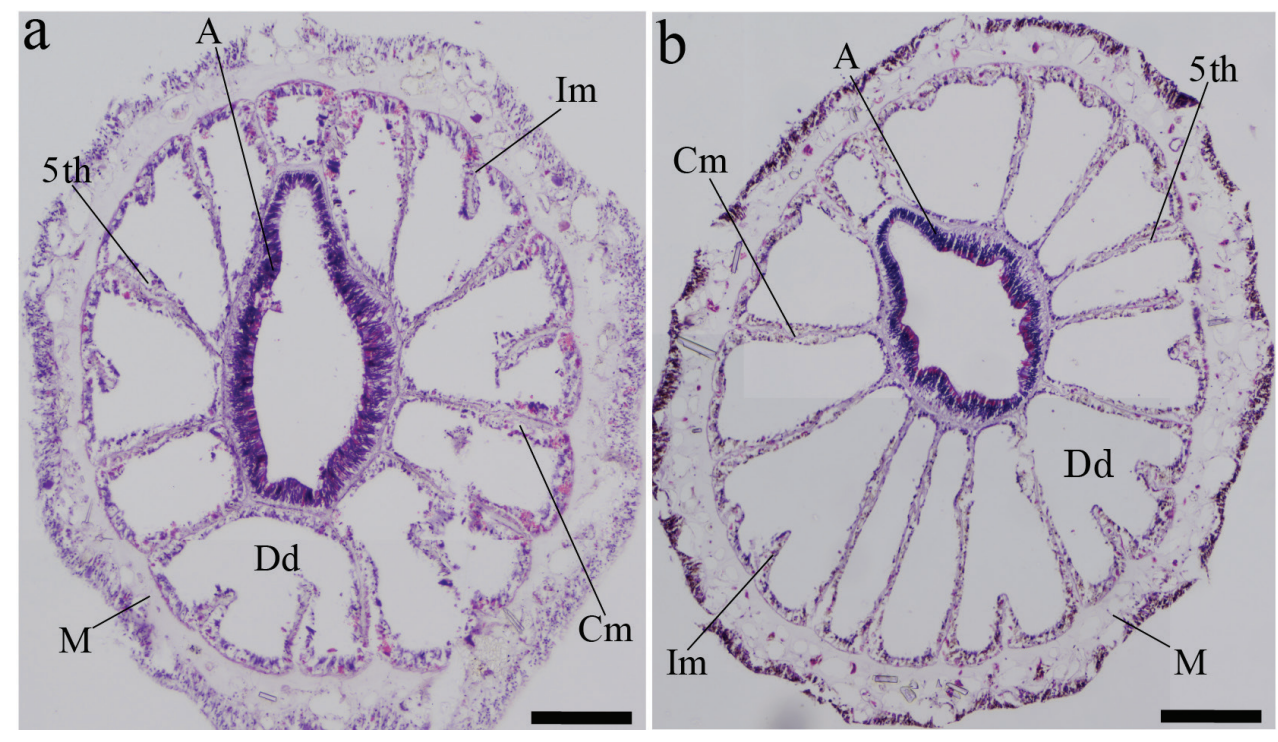

Figure 2. Cross-sections of Epizoanthus illoricatus and E. inazuma sp. n. a E. illoricatus; $6^{\text {th }}$ mesentery is incomplete from dorsal directive $\mathbf{b}$ E. inazuma sp. n. $6^{\text {th }}$ mesentery is complete from dorsal directive. Dd dorsal directive $\mathbf{A}$ actinopharnx $\mathbf{I m}$ incomplete mesentery $\mathbf{C m}$ complete mesentery $\mathbf{M}$ mesoglea; $5^{\text {th }}$, $5^{\text {th }}$ mesentery from dorsal directive. Scale bars: $200 \mu \mathrm{m}$.

Epizoanthus inazuma sp. n. is currently known only from Okinawa (Figure 1). However, it may be distributed in other locations in the Pacific Ocean, as it is likely this species has been confused with E. illoricatus and/or E. beriber sp. n. in the past due to their similar external morphology. E. illoricatus has been found in many areas of the western Pacific Ocean such as in New Caledonia (Sinniger 2006; Sinniger et al. 2009), the Yellow Sea, China (Pei 1999), Papua New Guinea (BW Hoeksema, pers. comm.), Australia (Lindsay et al. 2012), Taiwan (Reimer et al. 2013), and Palau (Reimer et al. 2014), and E. inazuma sp. n. may be similarly distributed.

Remarks. Epizoanthus inazuma sp. n., E. beriber, and E. illoricatus can be distinguished from most other Epizoanthus species by their specific substrate (eunicid worm tubes) in the Pacific Ocean. Acrozoanthus australiae (family Zoanthidae) is also associated with eunicid worm tubes, but $E$. inazuma sp. n. can be distinguished from $A$. australiae due to its mesenterial arrangement (the family Zoanthidae is within the suborder Brachycnemina), as well as by many obvious external features such as coloration, polyp size, and by being azooxanthellate ( $A$. australiae is zooxanthellate). E. inazuma sp. n. is very similar to E. illoricatus (Figure 4a, b, c, f), but can be distinguished by differing mesenterial arrangement (6th mesentery is complete as opposed to 6th mesentery being incomplete in E. illoricatus) (Figure 2). Epizoanthus inazuma sp. n. has different coloration than E. beriber sp. n., which is pale white. Epizoanthus inazuma sp. n. and E. illoricatus can have the same external coloration (black), but the cnidomes of these two species are different; E. illoricatus has large holotrichs in the column, pharynx 


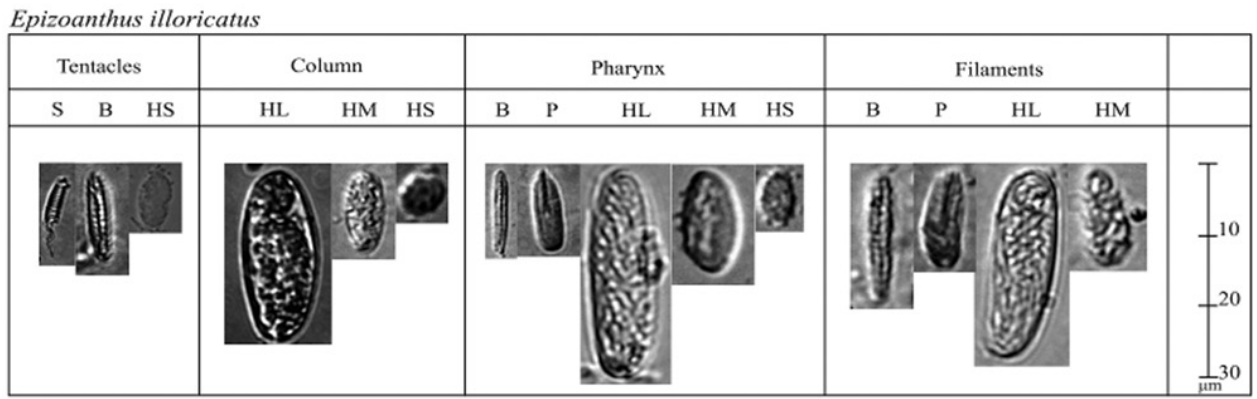

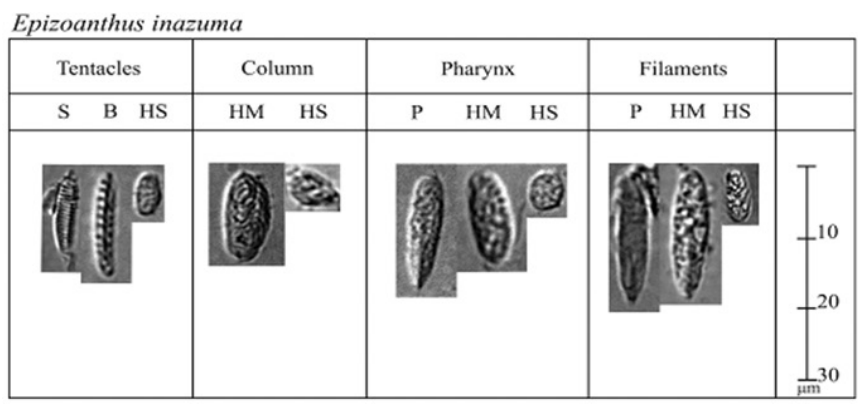

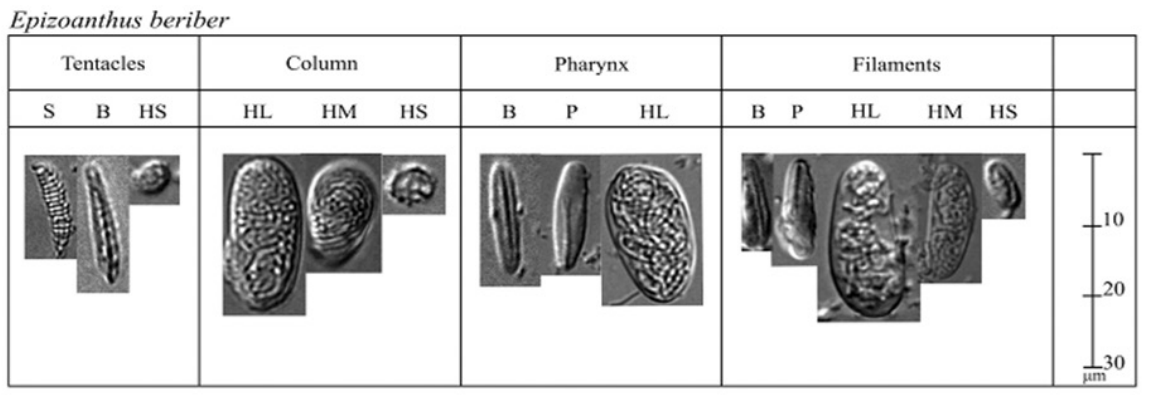

Figure 3. Cnidae in tentacles, column, pharynx, filaments of Epizoanthus illoricatus, E. inazuma sp. n. and E. beriber sp. n. respectively. HL holotrichs large HM holotrichs medium HS holotrichs small B basitrichs $\mathbf{p M}$ microbasic p-mastigophores $\mathbf{S}$ spirocysts.

and mesenterial filaments, while E. inazuma sp. n. does not have any large holotrichs in the column, pharynx, or mesenterial filaments. As well, there are also differences in sizes of some nematocyst types of these two species (e.g. bastrichs in the pharynx or mesenterial filaments). The cnidome composition of E. inazuma sp. n. is different from E. beribersp. n. and E. illoricatus, and E. beriber's sp. n. cnidome is similar to that of $E$. illoricatus (see Table 1; Figure 3).

All Indo-Pacific Epizoanthus species that are obligate epibionts on eunicid worm tubes until now have been identified as E. illoricatus, which was originally described 
from Manila, the Philippines. The type specimens of E. illoricatus were likely lost during World War II when the Zoologische Staatssammlung Museum in München was burned down. Additionally, no specific type locality was given except 'Manila' in the original description and Manila is now a very altered environment compared to 1930. Therefore, it is difficult to find and identify E. illoricatus' exact type locality. However, E. illoricatus can be clearly separated from E. inazuma sp. n. and E. beriber sp. n. by both morphological and molecular data.

\section{Epizoanthus beriber sp. $\mathrm{n}$.}

http://zoobank.org/7F0A1F6F-4922-4C2C-AF62-33948394AC97

Material examined. Holotype. NSMT-Co1575 (MISE-HK129), 7² $5^{\prime} 01.0^{\prime \prime} \mathrm{N}$, $134^{\circ} 15^{\prime} 80.0^{\prime}$ E, Turtle Cove, Palau, depth $20 \mathrm{~m}$, collected by Hiroki Kise, May 6, 2015, divided in two pieces, one portion fixed in $99.5 \% \mathrm{EtOH}$ and the other in $5-10 \%$ saltwater formalin, deposited in National Museum of Nature and Science, Tokyo, Japan. Paratype 1. RMNH 42101 (MISE-HK126), 70'29.4"N, $134^{\circ} 13^{\prime} 23.3$ "E, Blue Hole, Palau, depth 36 m, collected by Hiroki Kise, May 5, 2015, divided in two pieces, one portion fixed in $99.5 \% \mathrm{EtOH}$ and other in 5-10\% saltwater formalin, deposited in Naturalis Biodiversity Center, Leiden, The Netherlands. Paratype 2. USNM 1296758, USNM 1296759 (MISE-HK113), 7¹8'54.8"N, $134^{\circ} 13^{\prime} 13.3^{\prime \prime E}$, Siaes Tunnel, Palau, depth 30 m, collected by Hiroki Kise, April 28, 2015, divided in two pieces, one portion fixed in $99.5 \% \mathrm{EtOH}$ and other in 5-10\% saltwater formalin, deposited in Smithsonian Institution National Museum of Natural History, Washington, D.C., USA. Other material. MISE-HK112, $7^{\circ} 18^{\prime} 54.8^{\prime \prime} \mathrm{N}$, $134^{\circ} 13^{\prime} 13.3^{\prime \prime E}$, Siaes Tunnel, Palau, depth 37 m, collected by Hiroki Kise, April 28, 2015, divided in two pieces and fixed in $99.5 \% \mathrm{EtOH}$ and $5-10 \%$ saltwater formalin, respectively; MISE-HK116, $7^{\circ} 18^{\prime} 54.8^{\prime \prime} \mathrm{N}, 134^{\circ} 13^{\prime} 13.3^{\prime \prime E}$, Siaes Tunnel, Palau, depth unknown, collected by Hiroki Kise, April 28, 2015, divided in two pieces and fixed in $99.5 \% \mathrm{EtOH}$ and $5-10 \%$ saltwater formalin, respectively; MISE-HK117, $7^{\circ} 18^{\prime} 54.8^{\prime \prime N}, 134^{\circ} 13^{\prime} 13.3^{\prime \prime E}$, Siaes Tunnel, Palau, depth unknown, collected by Hiroki Kise, April 28, 2015, fixed in 99.5\% EtOH; MISE-HK118, 7¹8'54.8"N, $134^{\circ} 13^{\prime} 13.3^{\prime \prime E}$, Siaes Tunnel, Palau, depth unknown, collected by Hiroki Kise, April 28, 2015, fixed in 99.5\% EtOH; MISE-HK119, $7^{\circ} 18^{\prime} 54.8^{\prime \prime N}, 134^{\circ} 13^{\prime} 13.3^{\prime \prime E}$, Siaes Tunnel, Palau, depth 19 m, collected by Hiroki Kise, April 28, 2015, fixed in 99.5\%; MISE-HK120, $7^{\circ} 18^{\prime} 54.8^{\prime \prime} \mathrm{N}, 134^{\circ} 13^{\prime} 13.3^{\prime \prime} \mathrm{E}$, Siaes Tunnel, Palau, depth unknown, collected by Hiroki Kise, April 28, 2015, fixed in 99.5\% EtOH; MISEHK124, $8^{\circ} 19^{\prime} 00.0^{\prime \prime} \mathrm{N}, 134^{\circ} 63^{\prime} 00.0^{\prime \prime}$, Negruangel, Palau, depth $27 \mathrm{~m}$, collected by Hiroki Kise, April 29, 2015, fixed in 99.5\% EtOH; MISE-HK125, 7²'29.4"N, $134^{\circ} 13^{\prime} 23.3^{\prime \prime E}$, Blue Hole, Palau, depth $32 \mathrm{~m}$, collected by Hiroki Kise, May 5, 2015 , divided in two pieces and fixed in $99.5 \% \mathrm{EtOH}$ and $5-10 \%$ saltwater for-

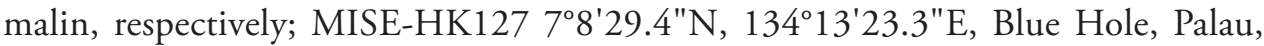
depth 36 m, collected by Hiroki Kise, May 5, 2015, fixed in 99.5\% EtOH; HK128 
$7^{\circ} 8^{\prime} 12.3^{\prime \prime} \mathrm{N}, 134^{\circ} 13^{\prime} 16.5^{\prime \prime} \mathrm{E}$, Blue Corner, Palau, depth $29 \mathrm{~m}$, collected by Hiroki Kise, May 5, 2015, fixed in 99.5\% EtOH.

Description of holotype. Colony of approximately 75 polyps connected by moderately developed coenenchyme on eunicid worm tubes. Polyps were attached to from base to proximal extremity of zig-zag shaped tubes of eunicid worms, and attached to not only bent sections but also to other locations. Polyps approximately 1.4 to $1.9 \mathrm{~mm}$ high from coenenchyme, and 0.7-1.0 mm in diameter. Azooxanthellate. Polyp external coloration is white, oral disk solid in color, ranging from light brown to brown (Figure 4d). Tentacles are transparent and approximately 20-22 in number.

Diagnosis. Morphology. Polyps connected by moderately developed coenenchyme on eunicid worm tubes belonging to the genus Eunice, as are Epizoanthus illoricatus and E. inazuma sp. n. Polyps are either circular cones or cylindrical, and approximately 0.5 to $2.1 \mathrm{~mm}$ high from coenenchyme (=length) and 1.1 to $2.1 \mathrm{~mm}$ diameter (in $5-10 \%$ seawater formalin). Maximum diameter of polyps is approximately $3 \mathrm{~mm}$, maximum height approximately $5 \mathrm{~mm}$ in situ. Polyps have 20-22 tentacles that are longer than oral disk diameter. In addition, polyp external color is white while oral disk is light brown to brown.

Internal anatomy. Mesogleal thickness approximately $80 \mu \mathrm{m}$. We could not obtain cross-sections or images to observe mesentery arrangement due to heavy sand encrustation.

Cnidae. Holotrichs, basitrichs, microbasic p-mastigophores, spirocysts (see Table 1, Figure 3).

Etymology. Epizoanthus beriber sp. n. is named after the legendary Beriber of Palauan folklore, who lived in a cave at Oikuul in Airai State, as this species has been found only in caves. Common Japanese name. 'Ziguzagu-yadori-sunaginchaku' (new Japanese name).

Distribution and habitat. Epizoanthus beriber sp. n. is found only on the floor or sides of caves, and always in association with eunicid worm tubes (Figure 4d, e). Specimens were collected from $20-40 \mathrm{~m}$ in this study. E. beriber sp. n. is known from Palau and Papua New Guinea (Figure 1). However, it may be distributed around the Pacific Ocean as we have speculated for E. inazuma sp. n.

Remarks. Epizoanthus beriber sp. n. can be distinguished from E. illoricatus and E. inazuma sp. n. by habitat and coloration. E. beriber sp. n. was found only in caves while E. inazuma sp. n. and E. illoricatus were found on reef slopes or flat reef floors. E. beriber sp. n. has white colonial polyps with a moderately developed coenenchyme (Figure 4d, e) while E. inazuma sp. n. has black colonial polyps with a well-developed coenenchyme and E. illoricatus has gray, yellow or black colonial polyps with a either poorly developed or well-developed coenenchyme (Figure 4a-c, f).

The holotype of E. illoricatus was presumably collected by dredging or net as there was no SCUBA in the 1930s; and it can be inferred that the holotype of E. illoricatus lived in a location where it could be collected by such a method, such as on a reef flat or reef slope. E. inazuma sp. n. is also found in such areas. However, E. beriber sp. n. is only known from underwater caves that cannot be easily accessed from the surface. 

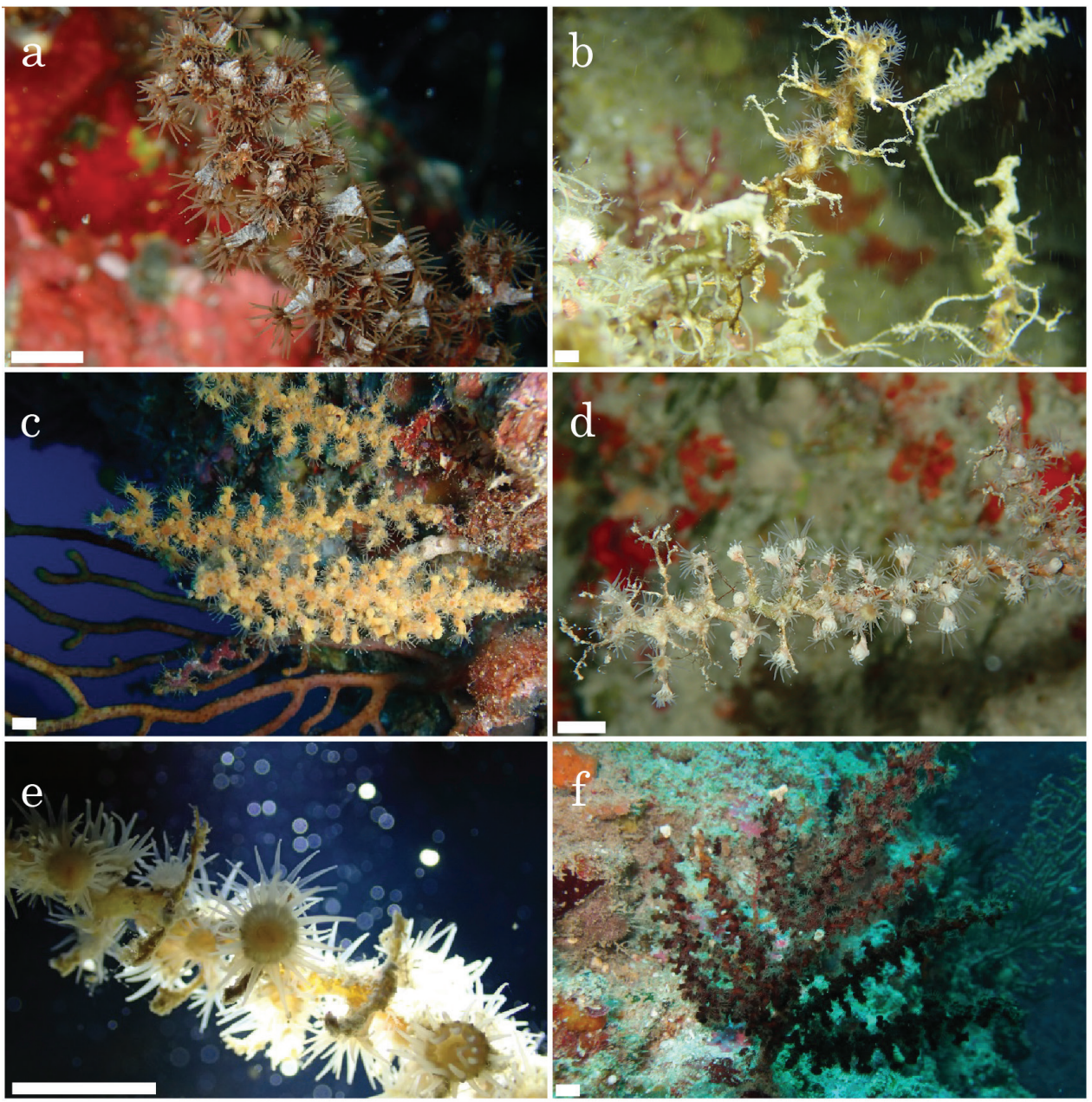

Figure 4. In situ images of Epizoanthus illoricatus, E. inazuma sp. n. and E. beriber sp. n. a E. illoricatus; with highly developed coenenchyme and high density of polyps. Image taken on September 12, 2014, at Siaes Tunnel, Palau. Specimen number HK67. Image taken by J. D. Reimer b E. illoricatus; with poorly developed coenenchyme and low density of polyps. Image taken on July 19, 2014, at Cape Manzamo, Okinawa, Japan. Specimen number HK53 c E. illoricatus; yellow colored colonies. Image taken on November 21, 2015, at Cape Manzamo, Okinawa, Japan. Specimen number HK100 d E. beriber sp. n.; with low density polyps. Image taken on May 6, 2015, at Turtle Cove, Palau. Specimen number HK129 (holotype) e E. beriber sp. n.; open polyps. Image taken on April 28, 2015, at Siaes Tunnel, Palau. Specimen number HK113 f E. inazuma sp. n.; black colored colony. Image taken on April 5, 2014, at Cape Manzamo, Okinawa, Japan. Specimen number HK54 (holotype). All images excepting specimen number HK67 taken by H. Kise. Scale bars: $3 \mathrm{~cm}$. 


\section{Phylogenetic analyses}

Sequences from Epizoanthus spp. specimens attached to eunicid worm tubes formed a large monophyletic clade along with other Epizoanthus spp. in the phylogenetic tree of all three DNA markers (Figures 5-7). The phylogenetic trees' topologies were very similar for all three DNA markers.

Although the morphological features of Epizoanthus inazuma sp. n. and E. beriber sp. n. were generally very similar to those of E. illoricatus, sequences were clearly separated into three monophyletic clades in the ITS-rDNA tree (Figure 5); all sequences of $E$. inazuma sp. n. were contained in a monophyletic clade with very strong support $(\mathrm{ML}=99 \% ; \mathrm{NJ}=100 \%$; Bayes $=1)$, and all sequences of $E$. beriber sp. n. were also contained in another monophyletic clade with very strong support $(\mathrm{ML}=100 \%$;

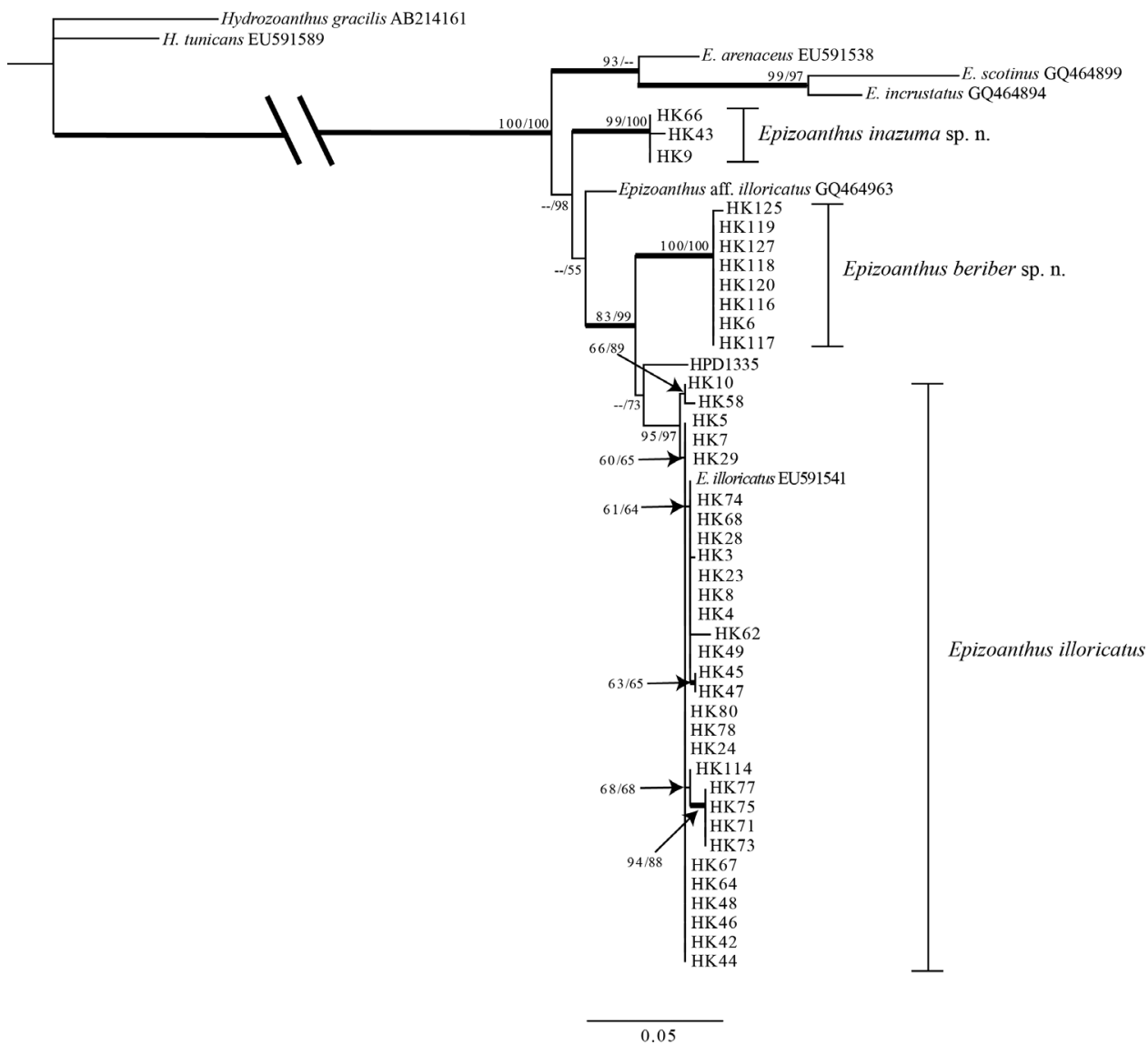

Figure 5. Maximum likelihood (ML) tree based on internal transcribed spacer region of ribosomal DNA sequence. Numbers on nodes represent ML and neighbor-joining (NJ) bootstrap values (> 50\% are shown). Bold branches indicate high supports of Bayesian posterior probabilities $(>0.95)$. Sequences obtained from GenBank are shown with accession numbers. 


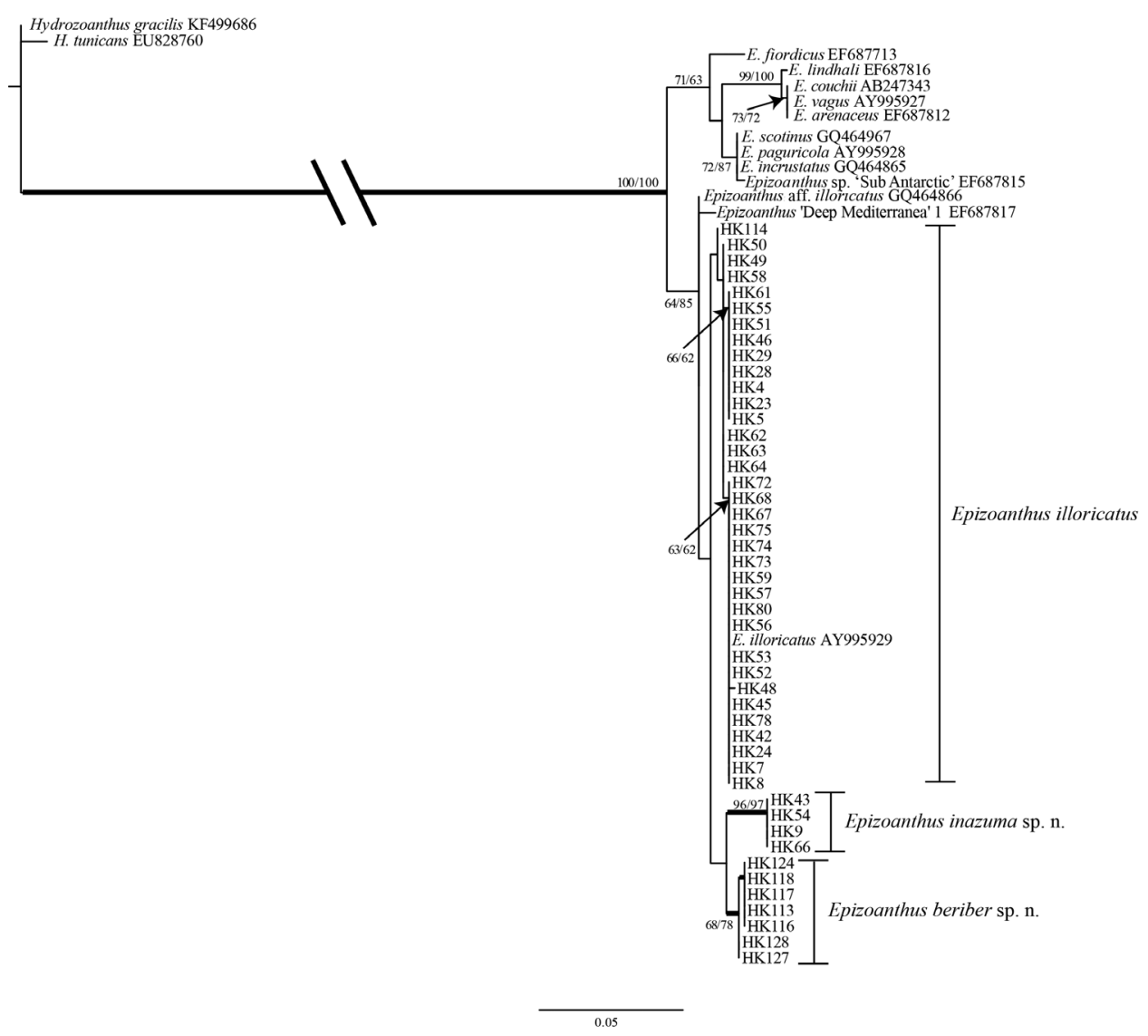

Figure 6. Maximum likelihood (ML) tree based on mitochondrial $16 \mathrm{~S}$ ribosomal DNA sequence. Numbers on nodes represent ML and neighbor-joining (NJ) bootstrap values (> 50\% are shown). Bold branches indicate high supports of Bayesian posterior probabilities ( $>0.95)$. Sequences obtained from GenBank are shown with accession numbers.

$\mathrm{NJ}=100 \%$; Bayes $=1$ ). All sequences of E. illoricatus, including previously reported sequences from GenBank, were contained in another monophyletic clade with strong support $(\mathrm{ML}=95 \%$; $\mathrm{NJ}=97 \%$; Bayes $=0.86)$.

The resulting trees from $\mathrm{mt} 16 \mathrm{~S}-\mathrm{rDNA}$ and COI sequences from specimens in this study also demonstrated that all three species were different (Figures 6-7, respectively); E. inazuma sp. n. and E. beriber sp. n. were each contained in monophyletic clades with moderate to strong support (COI: $\mathrm{ML}=98 \%$; $\mathrm{NJ}=100 \%$; Bayes $=1$; and $\mathrm{ML}=84 \%$; $\mathrm{NJ}=75 \%$; Bayes $=0.97:$ mt 16S-rDNA: $\mathrm{ML}=96 \% ; \mathrm{NJ}=97 \%$; Bayes $=0.99$; and $\mathrm{ML}=68 ; \mathrm{NJ}=78$ : Bayes $=0.98$; respectively). There were 5-6 bp differences between E. beriber sp. n. and E. illoricatus in the each of the mt 16S-rDNA and COI regions.

Previously reported sequences of Epizoanthus aff. illoricatus (ITS-rDNA: GQ464895; mt 16S-rDNA: GQ464866) from Station M, Monterey Bay, California, 


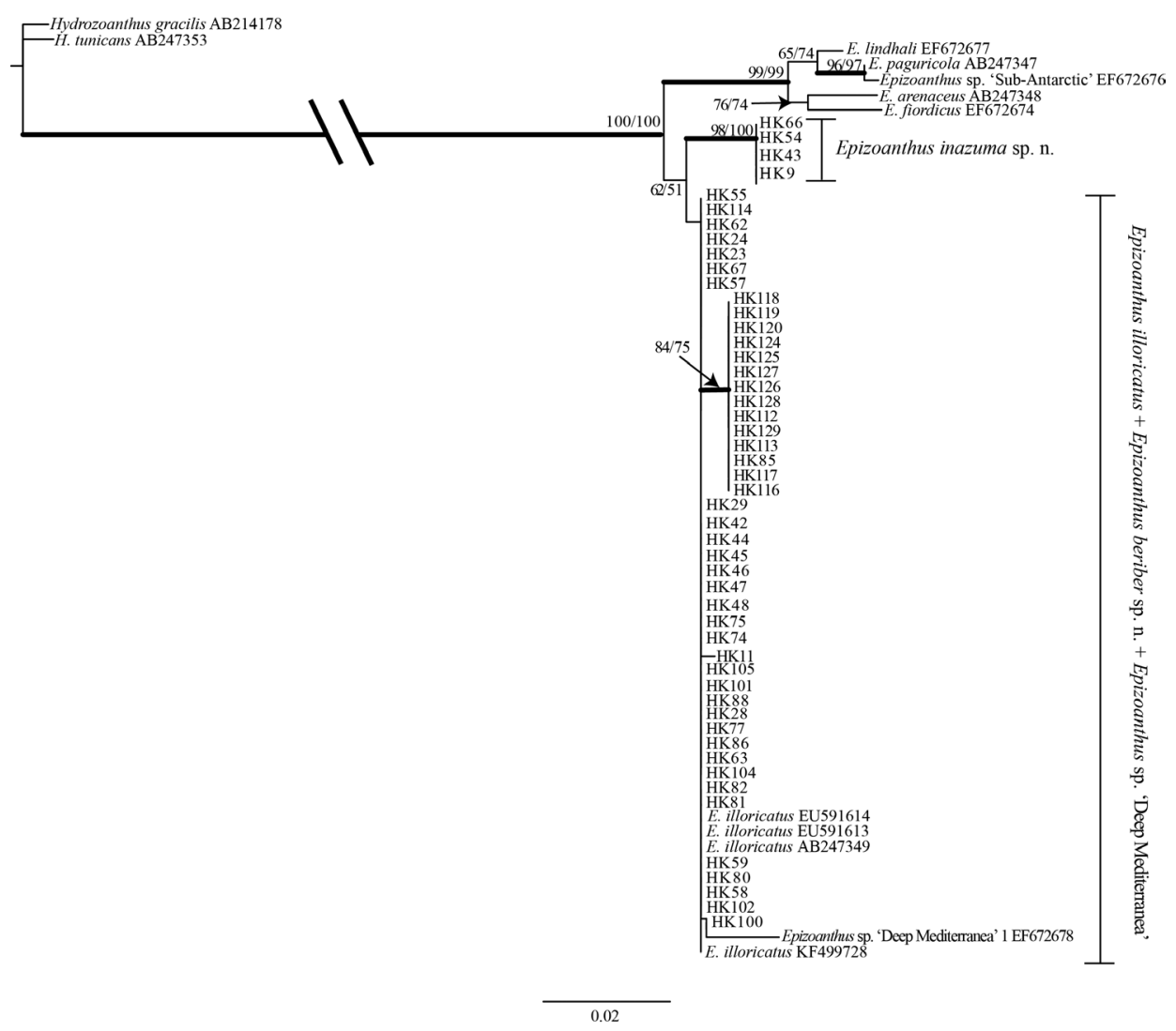

Figure 7. Maximum likelihood (ML) tree based on mitochondrial cytochrome oxidase subunit I sequence. Numbers on nodes represent ML and neighbor-joining (NJ) bootstrap values ( $>50 \%$ are shown). Bold branches indicate high supports of Bayesian posterior probabilities (>0.95). Sequences obtained from GenBank are shown with accession numbers.

USA were also contained within the clade of Epizoanthus spp. attached to eunicid worm tubes (Figures 5-6), although it is not clear which host this specimen was attached to (T. Swain, MorphBank collection number 477931 [MorphBank 2015]). In the ITS-rDNA tree, the sequence from this specimen was sister to a clade consisting of $E$. illoricatus and $E$. beriber sp. n. sequences with poor support $(\mathrm{ML}=<50 \%$; $\mathrm{NJ}=55 \%$; Bayes $=0.79)($ Figure 5), and was sister to the large E. illoricatus $+E$. inazuma sp. n. + E. beriber sp. n. clade in the mt $16 \mathrm{~S}$-rDNA tree (Figure 6). Previously reported sequences of Epizoanthus sp. 'Deep Mediterranea' 1 (mt 16S-rDNA: EF672678; COI: EF687817) were also contained in the clade of Epizoanthus spp. attached to eunicid worm tubes (Figures 6-7), although this specimen was apparently not associated with any living substrate (F. Sinniger, personal communication). This sequence was sister to a large, moderately well supported clade of E. illoricatus, E. inazuma sp. n., and E. beribersp. n. $(\mathrm{ML}=64 \% ; \mathrm{NJ}=85 \%$; Bayes $=0.55)$ in the $\mathrm{mt} 16 \mathrm{~S}$-rDNA tree (Figure 6), and was contained in a clade with E. illoricatus sequences in the COI tree (Figure 7). 


\section{Discussion}

Shallow Epizoanthus species associated with eunicid worm tubes are relatively common in the Pacific Ocean. However, until now there has been limited information about their diversity, and overall Epizoanthus species diversity is still relatively unknown and may be higher than has been originally thought (Reimer et al. 2010a). In this study two new species have been described, E. inazuma sp. n. and E. beriber sp. n. Based on these and previous findings (Sinniger et al. 2009; Reimer et al. 2010a), we believe there is a high potential of undescribed species being contained within already described Epizoanthus species. In this study, E. beriber sp. n. was only found in caves. Similarly, two Palythoa species that live in similar habitats have recently been described from Okinawa (Irei et al. 2015), and an azooxanthellate scleractinian coral species was also discovered in similar habitats in various Indo-West Pacific localities, including Palau (Hoeksema 2012). Such findings indicate that there may be high potential of the existence of more undescribed species in underwater caves or other 'cryptic' environments associated with coral reefs, and continued investigations of such environments are needed.

\section{Distinguishing characters of different Epizoanthus species attached to eunicid worm tubes}

Epizoanthus illoricatus has high levels of intraspecific morphological variation of some characters, such as external coloration, coenenchyme thickness, and polyp density (Figure $4 \mathrm{a}-\mathrm{c})$. Therefore, it may be easy to mistake different morphotypes as undescribed or potentially novel species by basing decisions only on morphological analyses, as has been suggested in other zoantharians (e.g. Burnett et al. 1997). In fact, although we collected some E. illoricatus specimens that had poorly developed coenenchymes with a low density of polyps, other specimens had a thin, highly developed coenenchyme with a high density of polyps (Figure 4a-b), and these two different morphotypes were not consistently recovered in different phylogenetic clades. Thus, although these two morphotypes had recently been speculated to be different species (Reimer et al. 2014), this does not appear to be an accurate delineation of species. Additionally, E. inazuma sp. n. looks very similar externally to E. illoricatus. Thus, E. illoricatus and E. inazuma sp. n. may be easily mistaken for each other due to these similar morphological characteristics.

However, phylogenetic analyses clearly showed that E. illoricatus and E. inazuma sp. n. are clearly distinct and each is within a well-supported monophyly (Figures 5-7), with genetic distances of $0.4 \%$ to $1.3 \%$ in mt $16 \mathrm{~S}$-rDNA and COI regions separating them. Previous literature has shown such genetic distances to be in line with interspecific differences among other zoantharian congeners (Reimer et al. 2006, 2010a; Sinniger et al. 2008; Irei et al. 2015).

Between E. illoricatus and E. inazuma sp. n. we found notable differences in mesenteriel arrangements (Figure 2) and in cnidae; and in particular clear differences based 
on the presence/absence of large holotrichs (Table 1, Figure 3). Mesenterial arrangement is usually used as a taxonomic character to divide suborders, however our morphological analyses in this study indicate that mesenterial arrangement is an unreliable indicator of suborder. The results of our study also suggest that in some cases mesenterial arrangement may be useful for species-level identification when combined with molecular analyses and data from other morphological characteristics.

Epizoanthus beriber sp. n. can be easily distinguished from E. illoricatus and E. inazuma sp. n. by habitat and polyp coloration (Figure 4a-f). In general, species identification based on coloration has been thought of as not generally reliable for brachycneminic zoantharians as much intraspecific variation is present (Burnett et al. 1995, 1997; Reimer et al. 2004), while it has been supposed that coloration may be considered useful for identification of some macrocnemic zoantharians (Sinniger et al. 2009, 2010). Here, we consider coloration of polyps as a potentially useful taxonomic characteristic in these Epizoanthus species when utilized in combination with habitat data and molecular analyses.

\section{Relationship between Epizoanthus spp. and eunicid worm tubes}

Epizoanthus illoricatus, E. inazuma sp. n. and E. beriber sp. n. are obligate epibionts on eunicid worms. Members of Eunicidae that host these Epizoanthus spp. make chitinlike zigzag tubes (Tischbierek 1930), and some colonies of E. illoricatus completely covered this substrate. In this study, we observed no E. illoricatus attached to tubes that did not have living eunicid worms inside. This means that $E$. illoricatus apparently has some kind of association with living eunicid worms; commensalism, mutualism, or parasitism. To understand this relationship, observations of the survival rate of Epizoanthus colonies with or without eunicid worms in both controlled laboratory settings and in situ are necessary. E. illoricatus and the two new species in this study do not produce tube-like structures such as a carcinoecium (Figure $4 \mathrm{a}-\mathrm{f}$ ), which is a corneous shell-like structure that has been observed in other Epizoanthus species' associations (e.g. hermit crabs; Schejter and Mantelatto 2011). In addition, because there are few morphological differences despite clearly distinct phylogenetic signals between $E$. illoricatus and E. inazuma sp. n., it is possible that the substrate consisting of eunicid worm tubes may be made by different host taxa (genus/species). Further research using molecular and morphological analyses of not only Epizoanthus but also of the Eunice host species are needed to understand these relationships better.

\section{Acknowledgements}

The first author would like to thank all members of the Molecular Invertebrate Systematics and Ecology Laboratory (MISE) at the University of the Ryukyus (UR) for 
their help in fieldwork and data collection. C. Timmons (MISE) proofread an earlier version of this manuscript. Dr. J. Lorion, G. Mereb and A. Merep at Palau International Coral Reef Center (PICRC) are thanked for logistical support. We also thank Dr. B.W. Hoeksema (Naturalis Biodiversity Center), Dr. T. Fujii (Kagoshima University) for providing invaluable specimens utilized in this study. Dr. F. Sinniger (UR) and Dr. T. Swain (Chicago Field Museum) kindly provided specimen information. Sampling in Palau was supported by the SATREPS P-CoRIE Project, funded by the Japan Science and Technology Agency and the Japan International Cooperation Agency in cooperation with PICRIC and Palau Community College. The senior author was also funded by the International Research Hub Project for Climate Change and Coral Reef/Island Dynamics at UR, and by a Japan Society for the Promotion of Science 'Zuno-Junkan' grant entitled 'Studies on origin and maintenance of marine biodiversity and systematic conservation planning'. Reviewer comments by Dr. J. Ryland, Dr. S. Stampar, and M. Risi greatly improved the manuscript. This is contribution PCoRIE Biodiversity \#5.

\section{References}

Ates RML (2003) A preliminary review of zoanthid-hermit crab symbioses (Cnidaria; Zoantharia/Crustacea, Paguridea). Zoologische Verhandelingen 180: 303-378.

Beaulieu SE (2001) Life on glass houses: sponge stalk communities in the deep sea. Marine Biology 138: 803-817. doi: 10.1007/s002270000500

Burnett WJ, Benzie JAH, Beardmore JA, Ryland JS (1995) Patterns of genetic subdivision in populations of a clonal cnidarian, Zoanthus coppingeri, from the Great Barrier Reef. Marine Biology 122: 665-673. doi: 10.1007/BF00350688

Burnett WJ, Benzie JAH, Beardmore JA, Ryland JS (1997) Zoanthids (Anthozoa, Hexacorallia) from the Great Barrier Reef and Torres Strait, Australia: systematics, evolution and a key to species. Coral Reefs 16: 55-68. doi: 10.1007/s003380050060

Carlgren O (1899) Zoantharien. Hamburger Magalhaensische Sammelreise 4: 1-48.

Carlgren O (1924) Die Larven der Ceriantharien, Zoantharien und Actiniarien. Deutsche Tiefsee-Expedition, 132-136.

Carlgren O (1934) Über einige ostasiatische Zoantharien. Arkiv för Zoologi 28A: 1-11.

Cutress CE (1971) Corallimorpharia, Actiniaria and Zoanthidea. Memoirs of the National Museum of Victoria (Melbourne) 32: 83-92.

Duerden JE (1898) Jamaican Actiniaria. Part I. Zoantheae. Royal Dublin Society 6: 330-332. England KW (1991) Nematocysts of sea anemones (Actiniaria, Ceriantharia and Corallimorpharia: Cnidaria): nomenclature. Hydrobiologia 216/217: 691-697. doi: 10.1007/ BF00026532

Fauchald K (1992) A review of the genus Eunice (Polychaeta: Eunicidae) based upon type material. Smithsonian Contributions to Zoology 523: 1-422. doi: 10.5479/si.00810282.523

Folmer O, Black M, Hoeh W, Lutz R, Vrijenhoek R (1994) DNA primers for amplification of mitochondrial cytochrome oxidase subunit I from diverse metazoan invertebrates. Molecular Marine Biology and Biotechnology 3: 294-299. 
Fujii T, Reimer JD (2011) Phylogeny of the highly divergent zoanthid family Microzoanthidae (Anthozoa, Hexacorallia) from the Pacific. Zoologica Scripta 40: 418-431. doi: 10.1111/j.1463-6409.2011.00479.x

Gravier C (1918) Note sur une actinie (* Thoracactis* n. g., *topsenti* n. sp.) et un annélide polychète (* Hermadion Fauveli* n. sp.), commensaux d'une éponge siliceuse (* Sa-rostegia oculata* Topsent). Bulletin de l'Institut Océano- graphique (Monaco) 344: 1-20. doi: 10.1093/sysbio/syq010

Guindon S, Dufayard JF, Lefort V, Anishmova M, Hordijk W, Gascuel O (2010) New algorithms and methods to estimate Maximum-likelihood phylogenies: Assessing the performance of PhyML 3.0. Systematic Biology 59(3): 307-321.

Haddon AC, Shackleton AM (1891) Actiniae: I. Zoantheae. Reports on the Zoological Collections Made in the Torres Straits by Professor A.C. Haddon, 1888-1889. Scientific Transactions of the Royal Dublin Society, Ser. 2, 4(13): 673-658.

Hertwig R (1888) Report on the Actiniaria dredged by H.M.S, Challenger during years 18731876. Reports Scientific Results Voyager Challenger (Zoology) 26: 39-41.

Hidaka M (1992) Use of nematocyst morphology for taxonomy of some related species of scleractinian corals. Galaxea 11:21-28.

Hidaka M, Miyazaki I, Yamazato K (1987) Nematocysts characteristic of the sweeper tentacles of the coral Galaxea fascicularis (Linnaeus). Galaxea 6: 195-207.

Hoeksema BW (2012) Forever in the dark: the cave-dwelling azooxanthellate reef coral Leptoseris troglodyta sp. n. (Scleractinia, Agariciidae). ZooKeys 228: 21-37. doi: 10.3897/zookeys. 228.3798

Hoeksema BW, Reimer JD (2015) Zoantharia. In: Fautin, Daphne G. (2011) Hexacorallians of the World. Accessed through: World Register of Marine Species at http://www.marinespecies.org/aphia.php? $\mathrm{p}=$ taxdetails\&id=607338 on 2015-11-05.

International Commission of Zoological Nomenclature [ICZN] (1991) Case 2750. Epizoanthus Gray, 1867 (Cnidaria, Anthozoa): proposed conservation. Bulletin of Zoological Nomenclature 48: 19-21.

Irei Y, Sinniger F, Reimer JD (2015) Descriptions of two azooxanthellate Palythoa species (Subclass Hexacorallia, Order Zoantharia) from the Ryukyu Archipelago, southern Japan. ZooKeys 478: 1-26. doi: 10.3897/zookeys.478.8512

Lindsay DJ, Uemura T, Yamamoto H, Ishibashi S, Nishikawa J, Reimer JD, Beaman RJ, Fitzpatrick R, Fujikura K, Maruyama T (2012) The untethered remotely operated vehicle PICASSO-1 and its deployment from chartered dive vessels for deep sea surveys off Okinawa, Japan, and Osprey Reef, Coral Sea, Australia. Marine Technology Society Journal 46: 4. doi: 10.4031/MTSJ.46.4.3

Lwowsky FF (1913) Revision der gattung Sidisia (Epizoanthus auct.), ein beitrag zur kenntnis der Zoanthiden. Zoologische Jahrbuecher Systematik 34: 557-613.

Martin D, Britayev TA (1998) Symbiotic polychaetes: review of known species. Oceanography and Marine Biology: an Annual Review 36: 217-340.

Montenegro J, Sinniger F, Reimer JD (2015) Unexpected diversity and new species in the sponge-Parazoanthidae association in southern Japan. Molecular Phylogenetics and Evolution 89: 73-90. doi: 10.1016/j.ympev.2015.04.002 
Morphbank: Biological Imaging (http://sky.www.morphbank.net/, 13 December 2015). Florida State University, Department of Scientific Computing, Tallahassee, FL 32306-4026 USA

Muirhead A, Tyler PA, Thurston MH (1986) Reproduction biology and growth of the genus Epizoanthus (Zoanthidea) from the north-east Atlantic. Journal of the Marine Biological Association of the United Kingdom 66: 131-143. doi: 10.1017/S0025315400039709

Neves G, Omena E (2003) Influence of sponge morphology on the composition of the polychaete associated fauna from Rocas Atoll, northeast Brazil. Coral Reefs 22: 123-129. doi: 10.1007/s00338-003-0295-4

Palumbi SR (1996) Nucleic acids II: the polymerase chain reaction. Molecular Systematics, 205-247.

Pei Z (1999) Fauna Sinica Coelenterata Actiniaria Ceriantharia Zoanthidae. Science Press, 202-203.

Philipp NA, Fautin DG (2009) Three new species of shallow water yellow zoanthids (Hexacorallia: Zoanthidea: Epizoanthidae) from southern California, USA, and southern Australia. Zootaxa 2058: 53-61.

Rees WJ (1967) A brief survey of the symbiotic associations of Cnidaria with Mollusca. Journal of Molluscan Studies 37: 213-231.

Reimer JD, Ono S, Fujiwara Y, Takishita K, Tsukahara J (2004) Reconsidering Zoanthus spp. diversity: molecular evidence of conspecifity within four previously presumed species. Zoological Science 21: 517-525. doi: 10.2108/zsj.21.517

Reimer JD, Ono S, Iwama A, Takishita K, Tsukahara J, Maruyama T (2006) Morphological and molecular revision of Zoanthus (Anthozoa: Hexacorallia) from southwestern Japan, with descriptions of two new species. Zoological Science 23: 261-275. doi: 10.2108/ zsj.23.261

Reimer JD, Hirose M, Nishikawa T, Sinniger, Itani G (2010a) Epizoanthus spp. associations revealed using DNA markers: a case study from Kochi, Japan. Zoological Science 27: 729_ 734. doi: 10.2108/zsj.27.729

Reimer JD, Nakachi S, Hirose M, Hirose E, Hashiguchi S (2010b) Using hydrofluoric acid for morphological investigations of zoanthids (Cnidaria: Anthozoa): a critical assessment of methodology and necessity. Marine Biotechnology 12: 605-617. doi: 10.1007/s10126009-9249-3

Reimer JD, Irei Y, Fujii T, Yang SY (2013) Molecular analyses of shallow-water zooxanthellate zoanthids (Cnidaria: Hexacorallia) from Taiwan and their Symbiodinium spp. Zoological Studies 52: 38. doi: 10.1186/1810-522X-52-38

Reimer JD, Poliseno A, Hoeksema BW (2014) Shallow-water zoantharians (Cnidaria, Hexacorallia) from the Central Indo-Pacific. ZooKeys 444: 1-57. doi: 10.3897/zookeys.444.7537

Rodriguez F, Oliver JL, Marin A, Medina JR (1990) The general stochastic model of nucleotide substitution. Journal of Theoretical Biology 142: 485-501. doi: 10.1016/S00225193(05)80104-3

Ronquist F, Huelsenbeck JP (2003) MrBayes 3: Bayesian phylogenetic inference under mixed models. Bioinformatics 19: 1572-1574. doi: 10.1093/bioinformatics/btg180

Ryland JS, Lancaster JE (2004) A review of zoanthid nematocyst types and their population structure. Hydrobiologia 530/531: 179-187. doi: 10.1007/s10750-004-2685-1 
Saitou N, Nei M (1987) The neighbor-joining method: a new method for reconstructing phylogenetic trees. Molecular Biology Evolution 4: 406-425.

Schejter L, Mantelatto FL (2011) Shelter association between the hermit crab Sympagurus dimorphus and the zoanthid Epizoanthus paguricola in the southwestern Atlantic Ocean. Acta Zoologica 92: 141-149. doi: 10.1111/j.1463-6395.2009.00440.x

Schmidt H (1974) On evolution in the Anthozoa. Proceedings of the 2nd International Coral Reef Symposium, Brisbane 1: 533-560.

Sinniger F (2006) Zoanthids of New Caledonia. In: Payri C, Richier de Forges B (Eds) Compen- dium of marine species from New Caledonia. IRD Editions, Noumea, 127-128.

Sinniger F, Häussermann V (2009) Zoanthids (Cnidaria: Hexacorallia: Zoantharia) from shallow waters of the southern Chilean fjord region, with descriptions of a new genus and two new species. Organisms, Diversity and Evolution 9: 23-36. doi: 10.1016/j.ode.2008.10.003

Sinniger F, Montoya-Burgos JI, Chevaldonne P, Pawlowski J (2005) Phylogeny of the order Zoantharia (Anthozoa, Hexacorallia) based on the mitochondrial ribosomal genes. Marine Biology 147: 1121-1128. doi: 10.1007/s00227-005-0016-3

Sinniger F, Reimer JD, Pawlowski J (2008) Potential of DNA sequences to identify zoanthids (Cnidaria: Zoantharia). Zoological Science 25: 1253-1260. doi: 10.2108/zsj.25.1253

Sinniger F, Reimer JD, Pawlowski J (2010) The Parazoanthidae (Hexacorallia: Zoantharia) DNA taxonomy: description of two new genera. Marine Biodiversity 40: 57-70. doi: 10.1007/s12526-009-0034-3

Swain TD (2009) Phylogeny-based species delimitations and the evolution of host associations in symbiotic zoanthids (Anthozoa, Zoanthidea) of the wider Caribbean region. Zoological Journal of the Linnean Society 156: 223-238. doi: 10.1111/j.1096-3642.2008.00513.x

Swain TD, Schellinger JL, Strimaitis AM, Reuter KE (2015) Evolution of anthozoan polyp retraction mechanisms: convergent functional morphology and evolutionary allometry of the marginal musculature in order Zoanthidea (Cnidaria: Anthozoa: Hexacorallia). BMC Evolutionary Biology 15: 123. doi: 10.1186/s12862-015-0406-1

Tamura K, Stecher G, Perterson D, Filipski A, Kumar S (2013) MEGA6: Molecular Evolutionary Genetics Analysis Version 6.0. Molecular Biology and Evolution 30: 2725-2729. doi: $10.1093 / \mathrm{molbev} / \mathrm{mst} 197$

Thompson JD, Higgins DG, Gibson TJ (1994) CLUSTAL W: Improving the sensitivity of progressive multiple sequence alignment through sequencing weighting, position-specific gap penalties and weight matrix choice. Nucleic Acids Research 22: 4673-4680. doi: $10.1093 /$ nar/22.22.4673

Tischbierek H (1930) Zoanthiden auf Wurmröhren. Zoologischer Anzeiger 91: 91-95.

Verrill AE (1882) Notice of the remarkable marine fauna occupying the outer banks off the southern coast of New England. American Journal of Science (3) 23: 135-142. doi: 10.2475/ajs.s3-23.134.135

Wood RL (1958) Identification and microanatomical study of a new species of Epizoanthus (Zoanthidea). Dissertation, University of Washington, Seattle.

Zanol J, Halanych KM, Fauchald K (2013) Reconciling taxonomy and phylogeny in the bristleworm family Eunicidae (Polychaete, Annelida). The Norwegian Academy of Science and Letters 43: 79-100. 


\section{Supplementary material I}

GenBank accession number, name and details of the sequences used in phylogenetic analyses of COI, mt 16S-rDNA and ITS-rDNA in this study

Authors: Hiroki Kise, James Davis Reimer

Data type: GenBank accession numbers

Copyright notice: This dataset is made available under the Open Database License (http://opendatacommons.org/licenses/odbl/1.0/). The Open Database License $(\mathrm{ODbL})$ is a license agreement intended to allow users to freely share, modify, and use this Dataset while maintaining this same freedom for others, provided that the original source and author(s) are credited.

\section{Supplementary material 2}

\section{List of examined specimens, and GenBank accession numbers}

Authors: Hiroki Kise, James Davis Reimer

Data type: GenBank accession numbers

Copyright notice: This dataset is made available under the Open Database License (http://opendatacommons.org/licenses/odbl/1.0/). The Open Database License $(\mathrm{ODbL})$ is a license agreement intended to allow users to freely share, modify, and use this Dataset while maintaining this same freedom for others, provided that the original source and author(s) are credited. 